\title{
ТЕОРИЯ
}

\section{ГЕОГРАФИЧЕСКАЯ ЭТИКА В ВЕК ГЛОБАЛИЗАЦИИ}

\author{
Тишков А. А.
}

Проблемь географической этики, возникающие в условиях глобализации, могут быть объяснимы с позиций постмодернизма. Современная география в прочессе формирования ответов на глобальные вызовы - демографические, геополитические, экологические, климатические, коммуникационные, информационные - сталкивается с необходимостью соблюдения норм географической этики, нравственного выбора при анализе и синтезе географических данных, картографировании, моделировании и прогнозировании будущуих состояний окружающего мира. На конкретных примерах рассмотрено применение основ географической этики в решении вопросов пространственного развития и устойчивого природопользования. Обсуждается необходимость дальнейшей гуманизации географии.

Ключевые слова: географическая этика, глобализачия, постмодернизм, плюрализм, релятивизм, вариантность, географический прогноз, алармизм, объективизм, гуманизаџия науки.

The problems of geographical ethics that arise in the context of globalization can be explained from the standpoint of postmodernism. Modern geography in the process of forming responses to global challenges - demographic, geopolitical, environmental, climatic, communication, information - is facing with the need to comply with the norms of geographical ethics, moral choice in the analysis and synthesis of geographical data, mapping, modeling and forecasting of future states of the environment. The application of the principles of geographical ethics in solving the issues of spatial development and sustainable nature management is considered using specific examples. The necessity of further humanization of geography is discussed.

Keywords: geographical ethics, globalization, postmodernism, pluralism, relativism, variation, geographical forecast, alarmism, objectivism, humanization of science.

Как синтетическая наука, охватывающая науки естественного и гуманитарного циклов, география в XXI в. - веке глобализации - оказалась подвержена веяниям постмодернизма. Главным его проявлением в нашей науке стало изменение типа раџиональности. Привычная для географии объективность восприятия

${ }^{*}$ Статья подготовлена в рамках темы государственного задания № 0148-2019-0007 Института географии РАН.

** Тишков Аркадий Александрович - член-корреспондент РАН, профессор, г. н. с. Института географии РАН, заведующий лабораторией биогеографии. E-mail: tishkov@igras.ru.

Век глобализации 3/2021 3-18

DOI: $10.30884 / v g l o b / 2021.03 .01$ 
и описания окружающего мира стала подменяться продуктом рационального сознания, создаюшим теоретический мир, мир идеальных конструкций, гаджетных образов, которые начинают жить самостоятельной жизнью и принимаются за истину. Миллиарды «стихийных географов», воспринимающих глобализированный мир посредством доступных информационных продуктов из своих ноутбуков, айфонов и смартфонов, пополнили ряды «путешественников», принимающих меняющийся мир как набор компьютерных образов-картинок, «сотканных» из дистанционной информации и построенных с помощью ГИС-технологий.

Идеальные конструкции, модели, цифровые карты, схемы манипуляций, полученные с использованием исследовательских аппаратов, технологий или информационных потоков и моделей (на самом деле - «посредников»), а не прямым наблюдением, уже претендуют на окончательность и безусловность и подменяют собой реальную действительность, объективный изменчивый мир. Человек, попавший в плен такого рода регламентов и форматов, оказывается неспособным сопротивляться догматическому давлению и критически относиться к идеям, теориям и практикам географии, он загоняет себя в ограниченные представления об окружающем мире и о самом себе в нем, а рациональное сознание превращается в догму, стереотипы и образы.

Это веяние распространяется не на все сферы географии, но начинает расширять свои позиции. География постмодернизма - это наука идей плюрализма и релятивизма, вариантных заключений, несовместимых с конкретикой географического объекта (не образа!), но в тоже время она - преимущественно коммерческая. Тот самый капитализм, за который мы отдали душу в 1990-х гг., заставляет и географическую науку самоокупаться, быть «сферой услуг», обрекать форму «государственных заданий», наукометрических формул и удельных показателей стоимости «научного продукта». Науке так удобнее - иметь вариантность, множественность, относительность в отображениях реального мира, ответов на запросы общества. Она постепенно начинает зависеть от формата используемых «посредников» - не только на стадии получения первичных данных, но и на этапе синтеза. Так, построение цифровых карт на основе мультиспектральной космической съемки высокого разрешения, вроде бы приближающее географию к точным наукам, по сути, сохраняет «относительность» и «степень вероятности» в моделировании состояния поверхности Земли, так как дает представление о «заполнении» отдельных пикселей (например, 300×300 м, 30×30 м) «объектом картографирования» - леса, поля, поселения и пр.

Постмодернистская география постулирует, что нельзя четко провести грань между собственно реальным окружающим миром, созданием картины мира и набором «фиктивных образов», полученных с помощью «посредников» и «проводников», между континуумом и дискретностью. Получается, что эта реальность, как в физической, так и в экономической географии, соткана из фикций, а сами эти фикции сделались единственной реальностью. К этому следует добавить и некоторую эфемерность состояний географических объектов, включая человека и преобразуемую им среду, подверженных как внутренним (саморазвитие, антропогенез), так и внешним (влияние космоса, климатической системы и пр.) воздействиям. Остается мало действительно инвариантных позиций для географической науки. 
Поэтому вопрос о географической этике остается актуальным в век глобализации, постмодернизма, когда сама глобализация как объект исследований географии рассматривается и как моральная дилемма, имеющая несколько решений, и как «нарастающий ком» планетарных вызовов человечеству. Практически все эти вызовы имеют «географические корни» - демографические, геополитические, экологические, климатические, коммуникационные, информационные, медикогеографические. Если вслед за С. Хантингтоном [2003: 7] считать глобализацию «новым этапом истории, который ведет... к росту конфликтности в мире», то все проблемы выживания государств и их безопасности, культурной целостности и идентичности, сохранения географического и биологического разнообразия и пр. суть соблюдения географической этики при разработке рекомендаций по снижению конфликтности. Кратко можно определить некоторые актуальные направления географической этики:

1) соблюдение нравственных норм научного отражения и синтеза данных об окружающем мире и при интерпретации данных статистики;

2) отказ от восприятия труда, созидательной деятельности человека на планете как негативного фактора для природы;

3) отказ от объективизма и алармизма в представлении результатов географических исследований и экспертизы;

4) деидеологизация контекста при географическом сопоставлении континентов, регионов, территорий (например, Европы и Азии, Европы и России, стран Севера и Юга и т. д.);

5) борьба с включением в географический анализ вымышленных рубежей, границ, ярлыков, фобий, «образов врага», стереотипов мышления и крайностей географического детерминизма;

6) «вето» на актуализацию старых карт, старых государственных границ, наименований государств, регионов, форм государственности и пр. при «географическом» обосновании современных геополитических интересов стран и регионов;

7) соблюдение этики географического прогноза и ответственности исследователя за интерпретацию и экстраполяцию данных палеогеографических реконструкций.

\section{Для чего нужны географическая этика и ее принципы?}

Для достижения условий устойчивого развития и мира обществу необходимы смена мировоззрения, установление новых нравственных принципов и мотивация для следования этическим нормам и правилам в отношении изучаемых географических объектов. Опыт показывает, что даже при достаточности ресурсов и оптимальности внешних условий государство далеко не всегда способно устойчиво развиваться, создавать эффективную пространственную инфраструктуру хозяйства, минимизировать ущерб природе, решать трансграничные задачи и конфликты, делать инвестиционно привлекательными в стратегическом отношении регионы.

Поэтому среди главных принципов географической этики - обязательная передача стратегических географических знаний лицам, принимающим решения, и содействие обретению ими географического мышления. Политики, управленцы и бизнесмены должны получать от географов представления о том, как лучше и эффективнее организовать хозяйство в пространстве сообразно размещению при- 
родных и людских ресурсов при минимальных воздействиях на природу, как взаимодействовать с другими государствами и регионами. Любыми средствами географы должны просветить их и сделать единомышленниками. Конечно, это достигается не развернутыми статьями в научных журналах, например в «Ethics, Place \& Environment», а экспертными и просветительскими действиями.

Помимо целей, функций и задач географии как науки, у нее есть ответственная миссия - сохранение географического разнообразия мира, которое, помимо многообразия ландшафтов, объектов живой и неживой природы, включает многообразие народов, языков, культур, традиций, форм природопользования. В этом один из принципов географической этики.

Кроме того, она устанавливает и важный принциип повсеместности сохранения природbl, при реализации которого не может быть «охраняемых» и «неохраняемых» природных территорий, растений, животных, может быть только разный режим сохранения и использования. С этических позиций (вполне логично, что они антропоцентричные) созданный, преобразованный человеком в прочессе хозяйствования ландшафт требует такого же внимания и сохранения, как и природный.

К этому примыкает диалектическое понимание и этическая норма необходимости сохранения природы для устойчивого использования ее ресурсов. Этот принцип некоторыми исследователями и практиками охраны природы принимается в штыки. Но он положен в основу самых важных международных документов, регулирующих сохранение живой природы (например, Конвенции о биологическом разнообразии 1992 г.).

Осуществление хозяйственной деятельности ради человека (а не ради избыточного потребления), включая изъятие природных ресурсов, освоение новых территорий, создание инфраструктуры, не может рассматриваться как что-то безнравственное. Нельзя созидательный труд в порыве борьбы за охрану дикой природы объявлять чем-то низменным, негуманным, как это делают, например В. Борейко [2005] и некоторые наиболее рьяные сторонники экологической этики. Географическая этика в данном случае обращает внимание на необходимость минимизации воздействия и экологического ущерба, регламентации изъятия и отвода земель, на поиск альтернативных решений в осуществлении хозяйственных проектов. Эти позиции заложены в требованиях географической экспертизы.

Биоэтика и экологическая этика во всех случаях остаются на стороне живой природы и создание особо охраняемой природной территории рассматривают как своего рода компенсацию за антропогенные нарушения. С позиций географической этики тот же эффект территориальной охраны достигается оптимальной организацией пространства и ландшафтным планированием, при котором каждая территория имеет функцию целевого назначения, а совокупно они организуются в обязательный экологический каркас, который создает условия для повсеместности охраны природы.

Но в России в большинстве случаев заповедание земель приводит к возникновению сложных и часто неразрешимых конфликтов с населением или хозяйствующими субъектами. У географии и экологии нет различий в системе ценностей, но в географической этике важны интересы и природы, и субъектов природопользования - справедливое разделение выгод, компенсация и возмещчение потерь 
местного населения и бизнеса. Эти принципы обязательно закладываются в стратегиях регионального развития.

Существенным в географической этике является противодействие использованию географических знаний во вред обществу: для воспрепятствования сочиокультурному обмену и сближению народов, разжигания этнических и территориальных конфликтов, формирования негативного образа отдельных стран и народов, ложного представления об инвестиционной привлекательности регионов, искажения информации на картах (если это не отвечает требованиям безопасности страны), сокрытия оперативных сведений об опасности природных катастроф и пр.

Эти и многие другие принципы географической этики должны закладываться в эколого-географические основы пространственного развития и устойчивого природопользования, фундаментальные и прикладные географические исследования, географическое образование и просвещение.

\section{Гуманизация как составляющая географии века глобализации}

Можно надеяться, что гуманизация самой географии даст толчок к гуманизации сфер приложения ее знаний. Но, постоянно сталкиваясь с вопросами планирования географических исследований, организации программных решений в географии и систематизацией представлений о развитии отдельных географических дисциплин и междисциплинарных работ, автор обратил внимание на то, что любые методологические попытки включения в географический анализ и синтез человека автоматически возвращают ее в категорию описательной науки, ассоциируя географов с путешественниками. Действительно, русская географическая наука, и прежде всего университетская география, веками развивалась в блоке гуманитарных наук. Так, по уставу 1804 г. Московского университета она была представлена на двух кафедрах: 1) всемирной истории, статистики и географии и 2) истории, статистики и географии Российского государства. Правда, уже в 1819 г. самостоятельная кафедра географии была создана в Петербургском университете. Но смею заверить, что среди исследовательских парадигм всегда доминировали статистические, картографические, природоведческие и, конечно, гуманитарные. Так что удалось отстоять многоотраслевой, синтетический и междисциплинарный характер науки и даже включить в рубрикатор некоторые ее инновационные направления - геоинформационные и дистанционные исследования.

По образному выражению В. Каганского [2001], «путешествие - презентация пространства». Тогда «синдром путешественника» в географии заключается в механической констатации факта, состояния географического объекта, тренда его развития, реже - некоторой субъективной оценке, связанной в случае с изучением природного объекта - с проблемами охраны природы и геоэкологии, а в случае с изучением хозяйства и населения - с социально-экономическими проблемами развития. Инновационная география - география синтеза и прогноза, наука с высокой степенью гуманизации, исходно ориентированная даже в ретроспективных исследованиях на актуальную картину мира, создающая технологии пространственного развития во всех аспектах - геополитическом, экономическом, социальном, эколого-географическом. 
Ранее нами [Котляков, Тишков 2009] было показано, что развитию современной географии мешают недостаточный уровень ее гуманизации и отсутствие четких нравственных принципов во взаимодействии с практикой, в первую очередь отсутствие механизма ответственности перед будущими поколениями за интеграцию в повседневную деятельность человека географических знаний, результатов географической экспертизы и географических прогнозов. Речь идет об общих принципах организации географических исследований - от целеположения к синтезу, интерпретации и популяризации, которые определяли бы географическую этику и нравственные позиции исследователя, его ответственность перед будущим.

В основе многих современных этнических и территориальных конфликтов, в попытках формирования негативного образа отдельных стран и народов, создании ложных представлений об инвестиционной привлекательности региона, искажений информации в книгах, учебниках, мировых и национальных статистических сводках, географических атласах и картах лежат нарушения географической этики. Но методологически неправильно соизмерять ситуационные, разовые нарушения географической этики и ее системные мировоззренческие проявления, которые могут быть менее идеологизированными и политизированными, но от этого не менее негативными по последствиям для природы, хозяйства и населения.

Например, одним из часто встречающихся нарушений географической этики мировоззренческого уровня является отказ от актуализации предмета исследований. В этом контексте можно говорить о постмодернистских попытках подмены реального (физического) пространства воображсаемым или «третьим пространством» [Митин 2011; Soja 1996; Gregory 1994]. Как ни странно, но именно отсутствие в анализе и синтезе географических исследований актуальной картины приводит к ложному представлению о безграничных масштабах экстраполяционной значимости получаемых географических данных. Так, сведения о локальной фауне степного заповедника могут иметь ограничения экстраполяции в пределах 2-3 \% от прежнего ареала степной зоны, а данные о составе флоры и растительности зрелых девственных средне- и южнотаежных лесов Европейской России в диапазоне $10-15 \%$ их прежней площади тайги.

Большинство современных ландшафтов, экосистем и биот Северной Евразии (а также и других регионов планеты) - результат длительного, тысячелетнего антропоценогенеза под контролем человека (пожаров и рубки леса, выпаса скота, развития эрозии, регуляции стока, загрязнения среды и эвтрофирования водоемов, фрагментации ландшафта, избыточности и избирательности промысла, контроля численности животных и т. д.).

В середине XIX в. немецкий географ К. Риттер писал, что Земля не только самостоятельно развивается, но и служит ареной многообразной деятельности человека. Видный французский географ Элизе Реклю считал, что современную природу необходимо понимать как результат естественного и антропогенного воздействий и указывал, что география - социальная наука, которая стремится установить гармонию природы и человека. За прошедшие два века антропогенная эволюция затронула практически все компоненты природной среды [Котляков, Тишков 2009].

География конца XIX в. была противоречива в отношении определения предмета и содержания, что служило выражением ее дуалистического характера, со- 
единившего знания о природе Земли, преобразуемой человеком, со знаниями о человеке и обществе. Господствующим направлением этого периода, в противовес мнению Э. Реклю, было естественно-научное направление русской школы, во многом перенявшей взгляды А. Геттнера. А. Н. Краснов называл географию «философией естествознания», подразумевая ее синтетическое содержание и обязательную актуализацию предмета исследований, учитывающую и ее антропогенную составляющую. А. Геттнер [1925], как сторонник единой географии, сводил ее к страноведению и ландшафтоведению, рассматривая человека и последствия его деятельности как компоненты природного ландшафта.

С нашей точки зрения, отход от «геттнеровской географии» привел сначала советских, а затем и российских географов к отказу от актуализации предмета исследований, к обязательному разделению предметов и объектов исследований на природные и «неприродные», к нежеланию воспринимать идеи «буржуазной географии» о «заполненном пространстве», где всегда присутствует человек и следы его деятельности. По А. Геттнеру, предмет исследований географии - «индивидуальные земные пространства и места» [Геттнер 1925: 55], где человек с его духовной культурой является частью любого ограниченного пространства. По сути, именно такое понимание современного предмета исследований сделало географию наукой, изучающей антропоцен [Тишков 2015], в противовес дисциплинам, изучающим прошлые состояния природы без человека. В этой ситуации даже с методологических позиций постановка вопроса о новой эпохе в эволюции Земли - антропоиене - в нашей стране ранее не имела под собой фундаментальных оснований.

Можно по-разному оценивать соотносимость концепции антропоцена с идеями К. Риттера, Дж. Маршала, Э. Реклю, А. Геттнера, В. В. Докучаева и В. И. Вернадского, но важно признать методологическую ценность всех подходов, которые способны интегрировать географические знания и прогнозы в повседневную деятельность человека, не отдаляя (разделяя) и не противопоставляя человека и природу, что, с нашей точки зрения, можно считать нарушением норм географической этики [Котляков, Тишков 2009]. Определив начало новой геологической эпохи - антропоцена - мы, с одной стороны, по сути, предупреждаем человечество о коренных, часто необратимых перестройках природы, а с другой - даем мощный научный инструмент - географический прогноз, который связан с этикой и востребован обществом.

\section{Нравственные нормы анализа и синтеза географических данных}

Ни коммунизм как заманчивая идеологическая перспектива, ни «открытое» информационное общество постмодернизма, ни концепция устойчивого развития не останавливают современную дегуманизацию развития человечества. Постепенно и география становится наукой, изучающей последствия воздействия человека на природу, мало дающей для стратегии выживания и развития, для будущего.

Но достоверность и полнота информации, которую география получает при изучении современного состояния природы в его сравнении с прошлыми состояниями, нужны для формирования новых фундаментальных знаний, для интеграции науки в практическую деятельность людей. Нравственная составляющая здесь не в голых цифрах, графиках и таблицах, а в интерпретации первичных 
данных. Если изменения природы беспрецедентны по масштабам, а последствия угрожают будущим поколениям, то это должно быть донесено до сознания лиц, принимающих решения, и населения. И тем и другим нужно знать наилучшие технологии и образиьы пространственного развития страны и регионов, устойчивого природопользования и сохранения среды. Но в этом еще одна важная составляющая географической этики - поиск и донесение до человечества меры и нормы природопользования, равного доступа населения к природным и цивилизационным благам и качественной среде.

Поэтому и сама концепция устойчивого развития не должна перерасти в концепцию устойчивого потребления, как это происходит в отдельных развитых странах, строящих «экологический рай», формирующих «стерильную среду» за счет получения в избытке природных ресурсов извне, оставляя экологические издержки по месту их добывания. Географы-теоретики, обосновывающие такие схемы разделения труда и размещения производительных сил, рекомендующие высочайшие по экологичности технологии для использования в отдельных странах, устраняются от гуманистических идей. Но достаточно проследить географию любой экологичной и высокотехнологичной производственной цепочки, как выясняется (и это может и обязан сделать именно географ), что добыча, транспортировка и переработка сырья, производство «чистой энергии» и «экологического транспорта» - это разрушенные тысячи гектаров природных экосистем, загрязненные реки и атмосфера промышленных центров.

Способна ли современная география с позиций этики решать вопросы гуманизации развития? Наш профессиональный ответ - конечно, да! Но вот востребованность таких идей не определяется ни на глобальном, ни на национальном уровне. Нет социального заказа от развитых стран, а у стран «неразвитых», стран третьего мира нет средств на постановку таких исследований, да и не будут они рубить сук, на котором сидят, оставаясь странами с сырьевой экономикой, размещая у себя «грязные производства».

Почему? Во-первых, сохраняются глобальные демографические тенденичи, несмотря на оптимистичные прогнозы, с креном перенаселения в развивающихся странах. В 1804 г. население Земли достигло 1 млрд, в 2020 г. - более 7,8 млрд человек. До стабилизации населения Земли на уровне 9 млрд еще 30-50 лет. Более высокие темпы прироста потребления ресурсов как раз в тех странах, где сохраняются темпы роста населения. И если, например, страны БРИКС поставят своей целью достичь в обозримой перспективе уровня потребления (не уровня жизни) США или Германии, то это возможно только при быстром истощении ресурсов Земли и превращения ее суши и океана в безжизненное пространство. В соответствии с этим в странах с разным пространственным потенциалом будут меняться нагрузки на ресурсы и экосистемы. Во многих странах Европы, в том числе в России, Украине, а также в Японии, идет сокращение численности населения.

Во-вторых, к началу XXI в. на Земле оказалось нарушено (в основном аграрным производством) 65 \% поверхности суши, а около 40 \% полностью трансформировано. В Европе антропогенные экосистемы занимают более 85 \%, в Африке $51 \%$, в Азии - до 60 \%, в Австралии - 40 \%, в Северной Америке - 45 \%. Во многих странах доля природных экосистем не превышает $5 \%$, а в странах Западной 
Европы и в Японии они отсутствуют полностью. Исключение составляет Россия, где Великий Евразийский природный массив занимает около 60 \% территории.

Причины здесь в условиях глобализации лежат не только в сфере потребления невозобновляемых ресурсов, но преимущественно в сфере несовершенства глобальной регламентации природопользования, неэффективного мирового разделения труда, постоянного использования экологического и политического фактора в конкурентной борьбе производителей и в торговых войнах, а также в сфере низкого качества международного регулирования со стороны ВТО, конвенций и соглашений. Для географов это очевидно, так как регламентация потребления в развитых странах, огромные военные расходы пространственно избирательны, что создает эффекты разрушения и фрагментации ландшафтов, перехода от очагового разрушения среды к фронтальному, снижающему возможности самовосстановления природы. А суммарные военные расходы стран мира составляют более 2 трлн долларов. И если говорить о географической этике применительно к этой статистике, то не надо «закрывать глаза», говоря с пафосом об ущербе природе от сельского хозяйства и нефтедобычи, потому что эти и другие отрасли по своему назначению созидательные, а военная отрасль - разрушительная и для человека, и для природы.

В-третьих, в мире идет снижение удельных показателей обеспечения земельными ресурсами и экологического следа. Площадь первого на душу населения «сжалась» по сравнению с 1900 г. в 4 раза и составляет менее 2 га, а к 2050 г. сократится до 1,6 га. Что касается экологического следа, то он с ростом потребления снижается еще более быстрыми темпами. Это сочетается с изменением структуры землепользования, деградацией почвенного покрова, расширением процессов эрозии земель и опустынивания, которые поражают страны Африки и Азии. В них более половины населения занято в первичных производствах и непосредственно связано с использованием природных экосистем (например, пастбищ), теряющих способность к регенерации. Отрицательные значения экологического следа, то есть когда потребление ресурсов выше, чем их запасы в самой стране, наблюдаются в наши дни у многих развитых и развивающихся стран. Например, по данным портала Priroda.su [Экологический...], «лидерами» здесь выступают Объединенные Арабские Эмираты $(-9,8)$, Катар $(-8,0)$, Бельгия $(-6,7)$, Япония и США (по $-4,2)$, Украина и Азербайджан $(-1,1)$. У России и у других экологических доноров планеты (Бразилии, Австралии, Боливии, Канады) экологический след сохраняет положительные значения - от $+1,3$ до $+7,0$, но снижается.

В-четвертых, разрывы в уровнях природоохранной деятельности между развитыми и развивающимися странами возрастают, что в планетарных масштабах усиливает дестабилизацию и напряженность в мире. Так, одно из важных достижений развитых стран - рост площади лесов (в последние десятилетия около 30 тыс. км²). К этим странам присоединилась и Россия, но увеличение лесных площадей здесь идет за счет деградации аграрных площадей. В то же время уничтожение тропических лесов сохраняет годовую скорость около 100 тыс. км².

Природоохранные технологии, базирующиеся на эколого-географических методах защиты природы, могут и должны стать объектами гуманитарной помощи и безвозмездного трансфера от развитых стран к развивающимся. Но вопреки здравому смыслу и географической этике планы территориального развития 
и ландшафтного планирования развивающихся стран (преимущественно плоды деятельности географов развитых стран) включают все больше объектов «грязного производства». Так, в Африке более 60 \% ВВП создается вынесенными сюда экологически опасными производствами.

В-пятых, дефицит водных ресурсов и питьевой воды - одна из наиболее сложных проблем развития современной экономики Африки и Азии. Она связана в первую очередь с увеличением потребления воды (более 70 \% - сельским хозяйством), которая используется нерационально, общей деградацией окружающей среды и изменением климата. По глобальным сценариям (ГЕО-4), при продолжении текущих тенденций к 2025 г. 1,8 млрд человек будут жить в регионах с абсолютным дефицитом водных ресурсов, 2/3 мирового населения будут испытывать стресс водного недостатка. В 2050 г. в таких условиях могут оказаться более 5 млрд человек. При наличии у развитых стран технологий решения данной проблемы любые препятствия их передаче нуждающимся странам - нарушение нравственных принципов и преступление.

\section{Объективизм результатов географических исследований}

Игнорирование норм географической этики трудно обсуждать как масштабное явление века глобализации, но оно конкретно и событийно. Наиболее ярко объективизм интерпретации результатов географических исследований проявляется при осмыслении глобальных изменений климата и синергизма их воздействия на природу, хозяйство и население в сочетании с ростом антропогенных нагрузок на поверхность Земли. Проблема затронула все сферы жизни - политическую, социальную, экономическую и экологическую. То, что это следствие антропогенной трансформации биосферы, доведено, что называется, до каждого слушателя радио, пользователя ТВ и Интернета. Но то, что в истории планеты подобные тренды и циклы температуры повторяются регулярно, а природа и традиционное хозяйство имеют определенный адаптационный ресурс - широкую норму реакции, география с трудом доносит до населения. Как вести себя в этих условиях человечеству, населению страны? На этот вопрос, преодолевая конъюнктуру, должны ответить и географы. Именно о поведении человечества в условиях проявлений глобального экологического и климатического кризиса надо думать, используя в том числе и прогнозы географов [Пузаченко 1998; БестужевЛада, Наместникова 2001]. Иначе география из созидательной и стратегической превращается в алармистскую и априори идеологизированную науку.

Объективизм в географических исследованиях проявляется и в отношении расстановки акцентов при оценках трансформации экосистем и биоты Земли, сила которой всегда пропорцииональна потреблению ресурсов независимо от места потребления. Постиндустриальное, информационное общество не оставляет себе гуманитарного базиса для защиты от таких явлений, как нарастающее потребление, стремление к переносу «грязного производства» из развитых стран, нежелание компенсировать потери природно-ресурсного потенциала и природной ренты от экспорта ресурсов. Сохраняется его стремление к моделям монополярного мира (в разных вариантах) и мирового господства, возврату к холодной войне как соревнованию военных бюджетов и в конечном счете к неоправданному росту нагрузок на природные ресурсы. Новые идеологические основы образования, 
заложенные в него в последние десятилетия, не дали ожидаемых результатов поколения XXI в. не стали носителями новой идеологии мировой кооперации, мировой демилитаризации, разумного отношения к природе и ее ресурсам.

География таит в себе потенциал решения сложных задач территориальной организации хозяйства, развития инфраструктуры, оптимизации расселения и природопользования и устойчивого развития. Она предлагает организацию рациональной системы мониторинга, рецепты минимизации нарушения земель, регионально адаптированные схемы реабилитации нарушенных земель, развитие территориальной охраны природы и формирования «зеленого каркаса» - все это прикладные решения на основе объективных географических знаний.

В проблеме глобального изменения климата география не только ищет и находит аналоги современных изменений в прошлом, но и разрабатывает системы мер по профилактике и снижению негативных последствий «быстрых» климатических изменений для природы, хозяйства и населения. А проблеме продолжающейся деградаџии гуманитарных основ развития противопоставляет модели устойчивого развития и его стратегии. Разными странами накоплен большой опыт включения гуманитарных идей в систему общественной и экономической жизни, в первую очередь через ее пространственную организацию, формирования определенных норм отношения к природе и пр. Хорошо видно, что деидеологизация в России не дала позитивных импульсов для развития регионов. Гуманитарные основы даже не закладываются в стратегии экономики субъектов федерации.

\section{Ответственность перед будущим: географический прогноз}

Достижение целей развития - это согласование противоречий и поиск компромиссов в системе «природа - общество», в том числе:

- между воздействием на природу и необходимостью ее охраны;

- использованием ресурсов и сохранением их запасов;

- биологическим и социальным в природе человека;

- научно-техническим прогрессом и гуманизмом;

- ростом потребления и нравственными позициями самоограничения;

- традиционным и инновационным в развитии и пр.

Существует много подходов к разрешению этих противоречий и поиску компромиссов. Механизмы согласования или устранения противоречий имеют четкую эколого-географическую основу. В частности, научно-технический прогресс играет большую роль в повышении эффективности природопользования и энергосбережения и в минимизации негативных последствий хозяйственной деятельности. Для разрешения противоречий также значение имеют смена мировоззрения, установление и следование новым нравственным принципам, этическим нормам и правилам поведения по отношению к природной среде и ресурсам. Здесь важен и выбор оптимальных сценариев в глобальной стратегии развития человечества, учитывающей ассимиляционный потенциал биосферы и ее способность к самовосстановлению.

Среди методологических позиций формирования географического прогноза и взглядов на будущее Земли можно назвать такие:

- алармизм, ожидание скорых экологических катастроф и быстрого истощения ресурсов; 
- экологический оптимизм, или вера в возможности коэволюции, в переход мировой и национальных экономик к возобновляемым ресурсам;

- рационализм, вера в опережающее развитие науки, особенно гуманитарной, включение ее достижений в решение глобальных проблем;

- экологический реализм, использование позитивного опыта решения экологических проблем и регламентации воздействий на природу и пр.;

- биотическая регуляция, определение емкости биосферы по отношению к воздействиям человека, сохранение биоты и природных экосистем как «гарантов» ее устойчивости [Горшков 1995].

В дискуссии о взаимодействии природы и общества участвуют разные стороны, отражающие весь спектр гуманитарных воззрений на ответственность перед будущим. Среди них геисты (от «Гея» Д. Лавлока), которые говорят, что все на планете саморегулируется; армагеддонисты, ожидающие близкого конца света из-за экологического кризиса; изобилисты (оптимисты), для которых пределов развития нет и потенциал Земли достаточен; ращионалисты, объединяющие всех в поисках рецепта выхода из «затянувшейся болезни» - антропогенной деградации природной среды; наконец, равнодушные, рассуждающие, что на наш короткий век всего хватит. К сожалению, последнюю группу формируют и ученые экологи, географы, которые выбирают направлением своих исследований только фиксацию разрушения природной среды.

Общие позиции почти для всех названных категорий - необходимость сохранения биосферы в близком к исходному состоянию. Различия заключаются в прогнозах, сценариях, используемых методах, в определении необходимой пропорции в степени сохранности и преобразования среды.

Среди взглядов на пределы развития человечества и его воздействия на природу на фоне глобализации надо выделить представления Л. Х. и Д. Л. Медоузов [см.: Розенберг 2007] и академика Н. Н. Моисеева [Моисеев и др. 1985]. Известные модели Л. Х. и Д. Л. Медоузов можно рассматривать как возможные варианты реакции природы на антропогенную деятельность в условиях промышленного роста, сокращения природных ресурсов и загрязнения окружающей среды. Такой реакцией может быть и резкое сокращение населения Земли вследствие голода и болезней в отдельных регионах и социальных группах, в результате эпидемий или пандемий, геноцицда, военньх конфликтов, локальньхх войн, наконец, мировой войны.

Н. Н. Моисеев подчеркивает, что для сохранения цивилизации на планете необходимо проводить разумную глобальную демографическую, экономическую и социальную политику, направленную на контролируемое, но ненасильственное регулирование населения, мощное развитие наукоемкой, энерго- и ресурсосберегающей экономики, возможную сочиильную справедливость и включение гуманитарных принциипов развития.

Это отличает его взгляды на будущее от прогностических и стратегических построений В. И. Вернадского, А. Лотки, Дж. Лавлока, Д. Х. и Д. Л. Медоузов, В. И. Данилова-Данильяна, В. Г. Горшкова и др. Их прогнозы также опираются на необходимость сохранения окружающей среды с общегуманитарных позищий развития. Но все же на первое место они ставили и ставят естественно-научный аппарат прогнозирования и доказательств современных трендов и кризисов (мо- 
дели, теорию термодинамики, оценки емкости биосферы, экономический анализ и пр.).

Главное в реалиях практической деятельности географии XXI в. - это острая необходимость внедрения гуманитарных идей развития в механистические, по сути, взгляды на эволючию самоорганизующейся системы Земли и ее биосферы. Исходя из этого возникла концепция коэволюции природы и общества и «пределов развития», предложенная в свое время Н. Н. Моисеевым [2000], определились приоритеты социальной справедливости, поддерживающего развития и пр. Эти позиции стали аргументом в пользу принятия географией будущего того, что мотивация развития человечества может быть регламентирована, а оно само может быть управляемым не с позиций «мирового правительства», а с позиuий приобретенного внутреннего побуждения, связанного и с механизмом самосохранения. При этом пространство как ресурс и условие развития не может рассматриваться фактором ограничения, иначе в стратегии развития появляются мотивы нового освоения, экспансии, захвата и пр.

Именно технократический взгляд политиков, экономистов и многих экологов на формирование и решение экологических проблем и их же механистический взгляд на противодействие ухудшению природной среды не позволяют привнести в глобальное прогнозирование собственно гуманитарные идеи. Но для географов, исходно ориентированных на сочетание физических и гуманитарных оснований стратегии развития человечества, такой взгляд очевиден. Географический прогноз должен опираться на идеологическую основу, на прогноз достижений науки, а главное - на новую мотивацию поведения человека на нравственной основе.

\section{Географическая этика в условиях глобализации (вместо заключения)}

Глобальные вызовы могут получать адекватный ответ географов с позиций географической этики, иначе возникают антигуманистические «издержки» исследований, обосновывающие алармистские, реваншистские, политизированные, постмодернистские и корпоративные лоббистские рекомендации типа «золотого миллиарда», пересмотра государственных или признания «исторических» границ государств, географической «избирательности» пространственной трактовки последствий климатических аномалий, обязательности борьбы с «антропогенным потеплением» и призывов «управления климатом», введения «углеродного налога» для тех, кто и производит все составляющие «чистых технологий» и т. п. Это относится и к географическому прогнозу, особенно его «безответственной части», касающейся масштабов и сроков наступления тех или иных глобальных катастрофических явлений - дефицита ресурсов, аномально высоких температур, глобальных эпидемий, вымирания видов, подъема уровня океана и пр. [Тишков 2013]. Понятно, что многие угрозы (в отличие от глобальных вызовов) носят скорее гипотетический характер. Например, есть множество вполне естественных причин, вызывающих заметные климатические колебания, а глобальный климат может испытывать сильные флуктуации и без всяких антропогенных воздействий. Даже при фиксированном уровне солнечной радиации и постоянной концентрации парниковых газов на протяжении столетия колебание средней температуры поверхности Земли достигает 0,4 ${ }^{\circ} \mathrm{C}$ [см. статью в «Nature»: Hansen, Lacis 1990]. 
Сама трактовка взаимодействия Человека с Природой как «конфликта» задает тон дискуссии о географической этике. Приписывание человеку «вечной вины» за «экологическую нечистоплотность», вымирающую природу [Арутюнов 2007], на наш взгляд, ложно, в том числе с нравственно-этических позиций. Ведь нарушение биосферных функций природы происходит как при пасторально-патриархальном сельском хозяйстве, так и при реализации мечты зеленых - функционировании «возобновляемой» энергетики. А обе они несут ничуть не меньшую угрозу для природы, чем индустриализация. По оценкам В. Г. Горшкова [1995], для сохранения стабильности биосферы цивилизация не должна потреблять свыше $1 \%$ чистой первичной продукции глобальной биоты. Современное же прямое потребление продукции суши существенно больше (впрочем, в пределах, которые свойственны консументам в природных экосистемах). Но это только с антропоцентрических позиций Природа и Цивилизация - антагонисты. Цивилизация стремится использовать воспроизводимый Природой потенциал как ресурс своего развития, а Природа стремится компенсировать и «сгладить» это воздействие. Учение об антропоцене как раз приближает нас к пониманию позиции Человека «как части Природы» и новой ступени эволюции.

Географии полезно озаботиться проблемами собственной гуманизации и новыми этическими основами [Котляков, Тишков 2009; Cutchin 2002]. В начале XXI в. это сделать существенно легче, чем в периоды Великих географических открытий, колонизации Азии, Африки и Латинской Америки и континентальных и мировых войн, когда география теоретически помогала «нести бремя белых», экспансиям (расширению границ) государств, созданию союзов и даже аншлюсам. Сейчас у географии появилась важнейшая социальная функция - обоснования модели будущего, создания новых утопий (взамен коммунистических). И здесь без теории взаимосвязи прагматической этики и географического мышления не обойтись [Cutchin 2002]. А нам остается только сформулировать новые задачи географической науки для развития ее теории и связей с практикой сообразно с глобальными вызовами и надеждами на будущее.

\section{Лuтература}

Арутюнов В. С. Глобальное потепление: катастрофа или благо // Химия и жизнь. 2007. № 3. 2007. С. 16-22.

Бестужев-Лада И. В., Наместникова Г. А. Социальное прогнозирование. М. : Педагогическое общество России, 2001.

Борейко В. Прорыв в экологическую этику. 4-е изд., доп. Киев : Логос, 2005.

Геттнер А. Страноведение Европы. М., 1925.

Горшков В. Г. Физические и биологические основы устойчивой жизни. М. : ВИНИТИ, 1995.

Каганский В. Л. Культурный ландшафт и советское обитаемое пространство: сб. статей. М. : Новое литературное обозрение, 2001.

Котляков В. М., Тишков А. А. Стратегия устойчивого развития России в начале XXI века: инновационные векторы и место географического прогноза // Инновации. 2009. № 9. С. 74-81. 
Митин И. И. На пути к воображаемой географии: два поворота, три пространства // Топос. Философско-культурологический журнал. 2011. № 1. С. 62-73.

Моисеев Н. Н. Судьба цивилизации. Путь разума. М. : Языки русской культуры. 2000.

Моисеев Н. Н., Александров В. В., Тарко А. М. Человек и биосфера. Опыт системного анализа и эксперименты с моделями. М. : Наука, 1985.

Пузаченко Ю. Г. Методологические основы географического прогноза и охраны среды. М. : Изд-во УРАО, 1998.

Розенберг Г. С. Глобальное моделирование (к 35-летию выхода в свет «Пределов роста») // Самарская Лука. 2007. Т. 16. № 3(21). С. 588-598.

Тишков А. А. На наш век хватит? Климатический прогноз и географическая этика // Аграрное обозрение. 2013. № 5(39). С. 56-58.

Тишков А. А. Биогеография антропоцена Северной Евразии // Известия РАН. Серия географическая. 2015. № 6. С. 7-23.

Хантингтон С. Столкновение цивилизаций. М. : АСТ, 2003.

Экологический след и биологический потенциал [Электронный ресурc]. URL: https://priroda.su/item/2070.

Cutchin M. P. Ethics and Geography: Continuity and Emerging Syntheses // Progress in Human Geography. 2002. Vol. 26. No. 5 (Oct.). Pp. 656-664.

Hansen J. E., Lacis A. A. Sun and Dust Versus Greenhouse Gases: An Assessment of Their Relative Roles in Global Climate Change // Nature. 1990. Vol. 346. Pp. 713-719.

Gregory D. Geographical Imaginations. Cambridge, MA - Oxford : Blackwell, 1994. Pp. 1-25 [Электронный ресурc]. URL: https://studylib.net/doc/6850497/gregory-tahrir--geographical-imaginations (дата обращения: 18.01.2021).

Soja E. Thirdspace. Cambridge, MA : Blackwell Publishers Inc., 1996.

\section{References}

Arutyunov V. S. Global'noe poteplenie: katastrofa ili blago [Global Warming: A Disaster or a Blessing] // Himiya i zhizn'. 2007. No. 3. Pp. 16-22.

Bestuzhev-Lada I. V., Namestnikova G. A. Socialny prognoz [Social Forecasting]. Moscow : Pedagogical Society of Russia, 2001.

Boreyko V. Propyv v elologicheskuyu etiku [Breakthrough in Environmental Ethics]. $4^{\text {th }}$ ed. Kiev : Logos, 2005.

Hettner A. Stranovedeniye Yevropy [Country Geography of Europe]. Moscow, 1925.

Gorshkov V. G. Fizicheskie i biologicheskie osnovy ustoichivoi zhizni [Physical and Biological Bases of Sustainable Life]. Moscow : VINITI, 1995.

Kagansky V. L. Kulturny landshaft I sovetskoe obitaemoe prostranstvo [Cultural Landscape and Soviet Habitable Space] : collection of articles. Moscow : New Literary Review, 2001.

Kotlyakov V. M., Tishkov A. A. Strategiya ustoichivogo razvitiya Rossii v nachale 21 veka: innovatsionnye vektory i mesto geograficheskogo prognoza [Strategy of Sustainable Development of Russia at the Beginning of the 21st Century: Innovative Vectors and the Place of Geographical Forecast] // Innovatsii. 2009. No. 9. Pp. 74-81. 
Mitin I. I. Na puti k voobrazhaemoy geographii: dva povorota, tri prostranstva [On the Way to an Imaginary Geography: Two Turns, Three Spaces] // Topos. Philosophical and Cultural Journal. 2011. No. 1. Pp. 62-73.

Moiseev N. N. Sud'ba tsivilizatsii. Put' razuma [The Fate of Civilization. The Path of Reason]. Moscow : Yazyki russkoj kul'tury, 2000.

Moiseev N. N., Alexandrov V. V., Tarko A. M. Chelovek i biosfera. Opyt sistemnogo analiza i eksperimenty s modelyami [Man and the Biosphere. Experience of Systematic Analysis and Experiments with Models]. Moscow : Nauka, 1985.

Puzachenko Yu. G. Metodologicheskie osnovy geographicheskogo prognoza i okhrany sredy [Methodological Foundations of Geographical Forecasting and Environmental Protection]. Moscow : URAO Publishing House, 1998.

Rosenberg G. S. Globalnoe modelirovanie (k 35-letiuy publikatsii "Limits of Growth") [Global Modeling (To the 35th Anniversary of the Publication of "Limits of Growth")] // Samarskaya Luka. 2007. Vol. 16. No. 3(21). Pp. 588-598.

Tishkov A. A. Na nash vek hvatit? Klimaticheskij prognoz i geograficheskaya etika [Is it Enough for our Century? Climate Forecast and Geographical Ethics] // Agrarnoe obozrenie. 2013. No. 5(39). Pp. 56-58.

Tishkov A. A. Biogeografiya antropotsena Severnoj Evrazii [Biogeography of the Anthropocene of Northern Eurasia] // Izvestija RAN. Geography series. 2015. No. 6. Pp. 7-23.

Huntington S. Stolknovenie tsivilizatsij [The Clash of Civilizations]. Moscow : AST, 2003.

Ekologicheskiy sled i biologicheskiy potentsial [Ecological Footprint and Biological Potential]. URL: https://priroda.su/item/2070.

Cutchin M. P. Ethics and Geography: Continuity and Emerging Syntheses // Progress in Human Geography. 2002. Vol. 26. No. 5 (October). Pp. 656-664.

Hansen J. E., Lacis A. A. Sun and Dust Versus Greenhouse Gases: An Assessment of Their Relative Roles in Global Climate Change // Nature. 1990. Vol. 346. Pp. 713-719.

Gregory D. Geographical Imaginations. Cambridge, MA; Oxford : Blackwell, 1994. Pp. 1-25. URL: https://studylib.net/doc/6850497/gregory-tahrir---geographical-imaginations (accessed: 18.01.2021).

Soja E. Thirdspace. Cambridge, MA : Blackwell Publishers Inc., 1996. 